\title{
Selection and Properties of Streptococcus thermophilus Mutants Deficient in Urease
}

\author{
C. Monnet, ${ }^{1}$ S. Pernoud, ${ }^{1}$ A. Sepulchre, ${ }^{2}$ C. Fremaux ${ }^{2}$ and G. Corrieu ${ }^{1}$ \\ ${ }^{1}$ Unité Mixte de Recherche Génie et Microbiologie des Procédés Alimentaires, \\ Institut National de la Recherche Agronomique, 78850 Thiverval-Grignon, France \\ ${ }^{2}$ Rhodia-Food, 86220 Dangé Saint Romain, France
}

\begin{abstract}
Natural variations of the urea content of milk have a detrimental effect on the regularity of acidification by Streptococcus thermophilus strains used in dairy processes. The aim of the present study was to select ureasedeficient mutants of $S$. thermophilus and to investigate their properties. Using an improved screening medium on agar plates, mutants were selected from 4 different parent strains after mutagen treatment and by spontaneous mutation. Most mutants were stable and had a phage sensitivity profile similar to that of their parent strain. Some of them contained detrimental secondary mutations, as their acidifying activity was lower than that of the parent strain cultivated in the presence of the urease inhibitor flurofamide. The proportion of this type of mutant was much lower among spontaneous mutants than among mutants selected after mutagen treatment. Utilization of urease-deficient mutants in dairy processes may have several advantages, such as an increase in acidification, an improved regularity of acidification, and a lower production of ammonia in whey.
\end{abstract}

(Key words: Streptococcus thermophilus, acidifying activity, urease, spontaneous mutation)

Abbreviation key: NTG $=\mathrm{N}$-methyl-N'-nitro-N-nitrosoguanidine, $\mathbf{p H 1 5 h}=\mathrm{pH}$ after $15 \mathrm{~h}$ of growth, $\mathbf{t p H 5 . 6}=$ time necessary to reach $\mathrm{pH} 5.6$, ur(-) mutants $=$ mutants that are unable to hydrolyze urea.

\section{INTRODUCTION}

Strains of Streptococcus thermophilus are used in the manufacture of several kinds of cheeses and fermented milks. One of their main functions is the production of lactic acid, which assists in milk coagulation and curd draining. In contrast to the other lactic acid bacteria present in starter cultures, $S$. thermophilus possesses a urease that converts urea into ammonia and carbon

\footnotetext{
Received November 7, 2003.

Accepted January 23, 2004.

Corresponding author: C. Monnet; e-mail: monnet@grignon.inra.
} fr. dioxide (Juillard et al., 1988; Tinson et al., 1982a). During the growth of $S$. thermophilus in milk, production of ammonia from urea slows down the $\mathrm{pH}$ decrease or induces a temporary increase of $\mathrm{pH}$ (Latrille et al., 1992; Spinnler and Corrieu, 1989; Tinson et al., 1982a). Furthermore, urea metabolism by this bacterium also has an effect on its growth and lactic acid production (Pernoud et al., 2004). Depending on the strains and the growth stages of the cultures, consumption of urea induces either a faster or a slower $\mathrm{pH}$ decrease.

Natural variations in the urea content of milk have a detrimental effect on the regularity of acidification by $S$. thermophilus strains. As a consequence, several important sensory properties of the dairy products may be affected. For example, a high urea content in milk may lead to Reblochon cheeses with a higher moisture content (Martin et al., 1997). Therefore, it could be interesting to use urease-deficient strains in some cheese and fermented milk production processes. At least one naturally occurring urease-deficient strain (strain CNRZ407) has been described (Juillard et al., 1988). However, this strain does not meet the requirements for use in concentrated starter cultures (unpublished results). Furthermore, it would be important to constitute a collection composed of a high number of urease-deficient strains, as the appearance of new bacteriophages requires the frequent renewal of strains used in commercial starter cultures. An interesting approach would be to generate urease-deficient mutants from various parent strains with attractive technological properties for dairy processes. Tinson et al. (1982b) selected a urease-deficient mutant from $S$. thermophilus $\mathrm{TS}_{2}$ after mutagen treatment, but the acidifying properties of this strain had not been investigated. The aim of the present study was to select urease-deficient mutants from 4 different strains of $S$. thermophilus and to investigate some of their properties (stability, acidifying activity, and resistance to phages).

\section{MATERIALS AND METHODS}

\section{Parent Strains and Selection of Mutants}

Streptococcus thermophilus RD672, RD674, RD677, and RD678 were obtained from Rhodia Food (Dangé Saint Romain, France). 
For selecting mutants, $S$. thermophilus strains were grown at $37^{\circ} \mathrm{C}$ in $10 \mathrm{~mL}$ M17 broth (Terzaghi and Sandine, 1975). Cells were harvested by centrifugation at the end of the exponential growth phase, washed with $10 \mathrm{~mL}$ sodium phosphate buffer $(100 \mathrm{mM} ; \mathrm{pH} 7)$ and resuspended in $1 \mathrm{~mL}$ of buffer. The cell suspension was then mixed with $1 \mathrm{~mL}$ of a solution at a varying $\mathrm{N}$ methyl-N'-nitro-N-nitrosoguanidine (NTG) concentration, and the resulting mixture was incubated for $1 \mathrm{~h}$ at $37^{\circ} \mathrm{C}$. When spontaneous mutants were sought, NTG was replaced by water. The cells were recovered by centrifugation, washed with $2 \mathrm{~mL}$ sodium phosphate buffer, and resuspended in $10 \mathrm{~mL} \mathrm{M17} \mathrm{broth.} \mathrm{After} \mathrm{incubation}$ at $37^{\circ} \mathrm{C}$ for $1 \mathrm{~h}, 1 \mathrm{~mL}$ of culture was mixed with $7 \mathrm{~mL}$ of reconstituted skim milk ( $100 \mathrm{~g} / \mathrm{L})$ supplemented with $1.5 \%$ ( vol/vol) glycerol, and the resulting mixture was stored in liquid nitrogen.

Mutants were screened after thawing the NTGtreated cells for $5 \mathrm{~min}$ in a water bath at $37^{\circ} \mathrm{C}$. After a 100 -fold dilution in sodium phosphate buffer, the cells were dispersed with a mechanical blender (Ultra-Tur$\operatorname{rax}^{\circledR}$ model T25; Ika Labortechnik, Staufen, Germany) for $1 \mathrm{~min}$. They were then inoculated onto the screening medium to obtain approximately 100 colonies per agar plate (9-cm in diameter). The medium, which derived from M17 broth, contained tryptone $(2.5 \mathrm{~g} / \mathrm{L})$, peptic digest of meat $(2.5 \mathrm{~g} / \mathrm{L})$, papain digest of soybeans $(5 \mathrm{~g} / \mathrm{L})$, yeast extract $(2.5 \mathrm{~g} / \mathrm{L})$, meat extract $(5 \mathrm{~g} / \mathrm{L})$, saccharose $(5 \mathrm{~g} / \mathrm{L})$, sodium glycerophosphate $6 \mathrm{H}_{2} \mathrm{O}(19 \mathrm{~g} / \mathrm{L})$, magnesium sulfate $7 \mathrm{H}_{2} \mathrm{O}(0.25 \mathrm{~g} / \mathrm{L})$, ascorbic acid $(0.5 \mathrm{~g} / \mathrm{L})$, nickel sulfate $7 \mathrm{H}_{2} \mathrm{O}(10 \mathrm{mg} / \mathrm{L})$, and agar $(15 \mathrm{~g} / \mathrm{L})$. After adjusting its $\mathrm{pH}$ to 7.0 , it was autoclaved at $115^{\circ} \mathrm{C}$ for 15 min. Inoculated agar plates were incubated in anaerobic conditions (Genboxanaer ${ }^{\circledR}$; Biomérieux, Marcy l'Etoile, France) for $2 \mathrm{~d}$ at $37^{\circ} \mathrm{C}$. Twenty milliliters of a top agar solution were then poured on each agar plate. To prepare this solution, $15 \mathrm{~g}$ agar and $100 \mathrm{mg}$ bromothymol blue were dissolved in $1 \mathrm{~L}$ sodium phosphate buffer $(50 \mathrm{mM}$; $\mathrm{pH}$ 6) by heating at $95^{\circ} \mathrm{C}$. After cooling at $48^{\circ} \mathrm{C}, 10 \mathrm{~g}$ urea were added, and $\mathrm{HCl}(1 M)$ was added dropwise until the color became yellow. After solidification of the top agar, the plates were incubated for $2 \mathrm{~h}$ at $37^{\circ} \mathrm{C}$ and subsequently examined on a light box. Colonies that hydrolyzed urea were surrounded by a blue halo because of ammonia production. Colonies that failed to produce a blue halo were recovered and purified on M17 agar. It was checked that the corresponding clones were unable to hydrolyze urea when grown in milk.

\section{Measurement of the Acidifying Activity}

For comparing the acidifying activity of the mutants to that of the corresponding parent strain, the cell concentration used for inoculating milk has to be standard- ized. Twenty-four milliliters of reconstituted skim milk (100 g/L; Elle et Vire, Condé-sur-Vire, France) sterilized for $20 \mathrm{~min}$ at $120^{\circ} \mathrm{C}$ were inoculated with $480 \mu \mathrm{L}$ of a $S$. thermophilus culture in M17 broth. After incubation for $16 \mathrm{~h}$ at $37^{\circ} \mathrm{C}, 24 \mathrm{~mL}$ of milk and $2.4 \mathrm{~mL}$ of a sterile sodium glycerophosphate solution $(253.4 \mathrm{~g} / \mathrm{L}$ of sodium glycerophosphate $6 \mathrm{H}_{2} \mathrm{O}$ ) were added to the cell culture. Aliquots of this mixture $(1.8 \mathrm{~mL})$ were then stored at $-80^{\circ} \mathrm{C}$. Viable cell concentration in the frozen cultures was determined after thawing them for $5 \mathrm{~min}$ in a water bath at $37^{\circ} \mathrm{C}$. After dilution, cells were then inoculated onto M17 agar plates, which were incubated for $2 \mathrm{~d}$ at $37^{\circ} \mathrm{C}$.

The stock cultures stored at $-80^{\circ} \mathrm{C}$ were used to inoculate, at a concentration of $10^{6} \mathrm{cfu} / \mathrm{mL}, 150 \mathrm{~mL}$ of reconstituted skim milk (100 g/L; Elle et Vire, Condé-sur-Vire, France) that had been heated for $10 \mathrm{~min}$ at $90^{\circ} \mathrm{C}$. The culture flasks were then placed in a water bath at $37^{\circ} \mathrm{C}$, and the $\mathrm{pH}$ was continuously measured during $15 \mathrm{~h}$ using a CINAC system (Corrieu et al., 1988). The time necessary to reach $\mathrm{pH} 5.6$ (tpH5.6, in $\mathrm{min}$ ) and the $\mathrm{pH}$ after $15 \mathrm{~h}$ of growth (pH15h) were used to compare the acidifying activity of the strains. Some milk cultures were done in the presence of $10 \mu M$ of the urease inhibitor flurofamide (N-[diaminophosphinyl]-4-flurobenzamide; ICN, Orsay, France) (Pernoud et al., 2004). A concentrated stock solution of this compound was prepared at $400 \mu M$ and added to milk after sterilization by filtration $(0.22 \mu \mathrm{m})$.

\section{Assay of Urea}

Urea concentration was assayed using an enzymatic kit (Boehringer, Boehringer Mannheim GmbH, Mannheim, Germany) according to the manufacturer's instructions. Before the assays, the samples were centrifuged for $20 \mathrm{~min}$ at $21,000 \times \mathrm{g}$, and the supernatants were recovered.

\section{Assays of Urease Activity}

Streptococcus thermophilus strains were cultivated in M17 broth for $24 \mathrm{~h}$ at $37^{\circ} \mathrm{C}$, and subsequently inoculated at $1 \%(\mathrm{vol} / \mathrm{vol})$ in $100 \mathrm{~mL}$ of a modified M17 broth. The medium contained tryptone ( $10 \mathrm{~g} / \mathrm{L})$, yeast extract ( $5 \mathrm{~g} /$ $\mathrm{L})$, sodium glycerophosphate $6 \mathrm{H}_{2} \mathrm{O}(19 \mathrm{~g} / \mathrm{L})$, ascorbic acid $(0.5 \mathrm{~g} / \mathrm{L})$, magnesium sulfate $7 \mathrm{H}_{2} \mathrm{O}(0.25 \mathrm{~g} / \mathrm{L})$, nickel sulfate $7 \mathrm{H}_{2} \mathrm{O}(10 \mathrm{mg} / \mathrm{L})$, and glucose $(10 \mathrm{~g} / \mathrm{L})$. After adjusting its $\mathrm{pH}$ to 7.0 , it was autoclaved at $115^{\circ} \mathrm{C}$ for $15 \mathrm{~min}$. Culture flasks were incubated for $24 \mathrm{~h}$ at $37^{\circ} \mathrm{C}$, and cells were then harvested by centrifugation at $14,000 \times g$ and $4^{\circ} \mathrm{C}$ for $15 \mathrm{~min}$. They were washed with $100 \mathrm{~mL}$ sodium phosphate buffer (50 mM; pH 7), resuspended in $1 \mathrm{~mL}$ of HEPES (N-(2-hydroxyethyl)piperazine- $\mathrm{N}^{\prime}$-(2-ethane- 
sulfonic acid)) buffer (50 m $M$; pH 7.5) supplemented with $1 \mathrm{~m} M$ EDTA, and placed in a 2 mL-tube containing 600 $\mathrm{mg}$ glass beads $(0.1 \mathrm{~mm}$ diameter; PolyLabo, Strasbourg, France). Cells were then processed in a cell disruptor (FP120 FastPrep ${ }^{\mathrm{TM}}$; Savant Instruments Inc., Holbrook, $\mathrm{NY})$ at $4^{\circ} \mathrm{C}$ for $30 \mathrm{~s}$ at speed 6.5. After centrifugation at $21,000 \times g$ and $4^{\circ} \mathrm{C}$ for $5 \mathrm{~min}$, urease activity was determined in the supernatant by a method adapted from Juillard et al. (1988). The assay was carried out in HEPES buffer (50 $\mathrm{m} M$; pH 7.5) supplemented with 1 $\mathrm{m} M$ EDTA and $25 \mathrm{~m} M$ urea. Immediately, after cell-free extract addition, and $10 \mathrm{~min}$ later, a $10-\mu \mathrm{L}$ aliquot was mixed with $100 \mu \mathrm{L}$ trichloroacetic acid (15\%, vol/vol) to stop the reaction. After an incubation for $20 \mathrm{~min}$ at $4^{\circ} \mathrm{C}$, the mixture was centrifuged for $5 \mathrm{~min}$ at $21,000 \times \mathrm{g}$. Supernatant $(50 \mu \mathrm{L})$ was then mixed with $750 \mu \mathrm{L}$ of ultrapure water and $100 \mu \mathrm{L}$ of Nessler's reagent (Merck Eurolab, Fontenay-sous-Bois, France), and absorbance at $425 \mathrm{~nm}$ was read 2 min later. Ammonia concentration was calculated using ammonia chloride standard solutions. One enzyme unit was defined as that producing $1 \mu \mathrm{mol} \mathrm{ammonia/min}$ at $37^{\circ} \mathrm{C}$. Protein concentrations in cell-free extracts were determined by the method of Bradford (1976) using bovine serum albumin as a protein standard.

\section{Sensitivity to Bacteriophages}

Streptococcus thermophilus strains were cultivated in M17 broth for $24 \mathrm{~h}$ at $40^{\circ} \mathrm{C}$ and subsequently inoculated at $5 \%(\mathrm{vol} / \mathrm{vol})$ in the same medium. After an incubation at $40^{\circ} \mathrm{C}$ for $6 \mathrm{~h}, 1.5 \mathrm{~mL}$ of culture were inoculated onto a M17 agar plate supplemented with $10 \mathrm{mM} \mathrm{CaCl} 2$. The excess liquid culture was then removed, and $20 \mu \mathrm{L}$ of phage solutions were spotted on the agar plates. After incubation for $15 \mathrm{~h}$ at $40^{\circ} \mathrm{C}$ and in anaerobic conditions, the plates were examined for the presence of lysis zones. Forty-one bacteriophages from the Rhodia food collection were tested (strains 498, 801, 1246, 1247, 1248, 1249, $1254,1255,1272,1293,1295,1164,572,2139,1811$, $503,1073,1126,524,2736,2739,2753,2758,2759,2760$, $2761,2763,2764,2765,2771,925,1022,921,859,1765$, 2991, 2993, 2995, 1433, 2759, and 2737). These bacteriophages, which were isolated from cheese whey, are active on $S$. thermophilus strains.

\section{DNA Manipulation and Analysis}

Total DNA from $S$. thermophilus RD678 was extracted as previously described (Pospiesh and Neumann, 1995). Polymerase chain reaction amplifications were performed with a GeneAmp ${ }^{\circledR} 9700$ PCR system (Perkin Elmer Corp., Norwalk, CT) using Taq polymerase (Appligene Oncor, Illkirch, France). Oligonucleotides ur09 (5'-
GCTCACATTGGATGATAG-3'), ur06 (5'-CGCTCGAAA GAATGACTG-3'), ur05 (5'-GTATCGATCCACAGAAC CT-3'), and ur08 (5'-CCTTCACTTCCTTGACAG-3') were deduced from the $S$. salivarius urease operon sequence (Chen and Burne, 1995; Chen et al., 1998). The species $S$. salivarius is closely related to $S$. thermophilus (Farrow and Collins, 1984), and its urease operon contains 8 genes involved in urea consumption: ureI, ureA, ureB, ureC, ureE, ureF, ureG, and ureD (Chen et al., 1996). Polymerase chain reaction amplification from $S$. thermophilus genomic DNA with the 2 couples of oligonucleotides ur09/ur06 and ur05/ur08 yielded 2 fragments of 3.4 and $3.0 \mathrm{~kb}$, respectively (corresponding to the first and to the second part of the $S$. salivarius urease operon). These DNA fragments were cloned into the TO$\mathrm{PO}^{\circledR} \mathrm{XL}$ vector (Invitrogen, Groningen, The Netherlands) and transferred into Escherichia coli TOP10 according to the manufacturer's instructions. A BigDye terminator cycle sequencing ready reaction kit and a 310 Genetic Analyzer (Applied Biosystems, Foster City, CA) were used for DNA sequencing. Each strand was sequenced twice by using recombinant $E$. coli clones resulting from independent PCR products. The DNA sequences were analyzed with Genetics Computer Group sequence analysis software from the University of Winsconsin (Devereux et al., 1984) and Mail Fasta (National Center for Biotechnology Information).

Presence of deletions or insertion sequence elements in the urease operon of urease-deficient mutants was evaluated by performing PCR amplifications. Nine couples of oligonucleotides, deduced from the sequence of the urease operon from $S$. thermophilus RD678 were used: ur12 (5'-GTACGGGCTATATTGTCA-3')/ur41 (5'C CTCCTTAAATCAATGCT-3'), ur30 (5'-GGGGCAAGTG GTAAGCAT-3')/ur11 (5'-GCATACTCTTCACGATCC$\left.3^{\prime}\right)$, ur38 (5'-TTAGACTAGAAAGAGGAC-3')/ur40 (5'-G GGTTAGTTGATGATGGC-3'), ur39 (5'-GCCATCATCA ACTAACCC-3')/ur37 (5'-TACAAAAGAGGTTGGAGG$\left.3^{\prime}\right)$, ur36 (5'-CCTCCAACCTCTTTTGTA-3')/ur35 (5'-GC AAAGGGATTAATGTTC-3'), ur34 (5'-CCCCTACGCCA TGTGAAT- $\left.3^{\prime}\right) /$ ur26 (5'-TTAGGACATGAAAATAGG CG-3'), ur33 (5'-CGCCTATTCATGTCCTAA-3')/ur32 (5'-CTTACAAGTCCTCTAGTA-3'), ur31 (5'-TACTAGA GGACTTGTAAG-3')/ur17 (5'-TTTCTCAGGCTCTAAG AG-3'), and ur13 (5'-CCTTATACCAAATAGGCA-3')/ ur49 (5'-GGTTGGTCTCATGAGGAT-3'). The DNA amplifications with ur12/ur41 corresponded to the promoter and ureI, ur30/ur11 to ureA and ureB, ur38/ur40 to the first part of ureC, ur39/ur37 to the second part of ureC, ur36/ur35 to ure E, ur34/ur26 to ureF, ur33/ur32 to ure $G$, ur31/ur17 to the first part of ureD, and ur13/ur49 to the second part of ureD. Polymerase chain reaction products were analyzed on $1.2 \%$ agarose gels measuring $20 \times 20$ $\mathrm{cm}$. Tris borate EDTA buffer $(10 \mathrm{~m} M$ Tris, $45 \mathrm{~m} M$ boric 
acid, and 2.5 mM EDTA) was used as the gel and electrophoresis buffer. Electrophoreses were run for $6 \mathrm{~h} 30$ min at $100 \mathrm{~V}$ and $14^{\circ} \mathrm{C}$, and $100 \mathrm{bp}$ DNA Step Ladder (Promega, Charbonnières, France) was used as a molecular weight marker. These electrophoresis conditions made it possible to detect differences of size greater than approximately $50 \mathrm{bp}$.

\section{Statistical Analyses}

All milk cultures were repeated 3 times. Mean values of the acidification descriptors were compared using a Student test and were considered to be significantly different when $P<0.05$. Standard deviation values were $<0.08$ units and 25 min for $\mathrm{pH} 15 \mathrm{~h}$ and tpH5.6, respectively. Urease activity measurements were repeated three times using the same cell-free extract. For the strains that displayed a detectable activity, standard deviation values were $<0.09 \mathrm{U} / \mathrm{mg}$ protein.

\section{RESULTS}

\section{Selection of Mutants that do not Hydrolyze Urea}

Tinson et al. (1982b) selected a urease-deficient mutant using a screening method on agar plates. In this method, an agar overlay containing urea and bromocresol purple was poured onto M17 agar plates on which bacterial colonies had grown. However, with the 4 parent strains used in the present study, we were not able to screen a large number of colonies per agar plate, as many urea-hydrolyzing colonies failed to develop a purple color. This is why we improved the screening method (the final procedure is described in Materials and Methods). It appeared that the presence of saccharose in the growth medium instead of glucose or lactose considerably increased the color of urea-hydrolyzing colonies. Addition of nickel sulfate was also beneficial (active ureases contain nickel), as well as incubation of the agar plates at a temperature of $37^{\circ} \mathrm{C}$ after addition of the overlay. By using this improved screening method, it was possible to examine $>100$ colonies per $9-\mathrm{cm}$ diameter agar plate.

In general, the chemical mutagen NTG is used at a concentration that kills between 90 and $99 \%$ of the cells. To reduce occurrence of multiple mutations, we adjusted its concentration to obtain $50 \%$ lethality (Table 1). Numerous ur(-) mutants (mutants that are unable to hydrolyze urea) could be obtained from the 4 parent strains that were studied. Furthermore, it was observed that there was an unusually high spontaneous mutation rate. Indeed, in the absence of mutagen treatment, between 0.006 and $0.026 \%$ of the colonies did not hydrolyze urea. When grown in milk, the mutants selected after mutagen
Table 1. Selection of Streptococcus thermophilus ur(-) mutants ${ }^{1}$ after mutagen treatment and by spontaneous mutation.

\begin{tabular}{|c|c|c|c|c|}
\hline \multirow[b]{2}{*}{$\begin{array}{l}\text { Parent } \\
\text { strain }\end{array}$} & \multirow[b]{2}{*}{$\begin{array}{l}\text { Mutagen } \\
\text { treatment }\end{array}$} & \multirow[b]{2}{*}{$\begin{array}{l}\text { Number } \\
\text { of colonies } \\
\text { examined }\end{array}$} & \multicolumn{2}{|c|}{ ur(-) mutants } \\
\hline & & & Number & $\begin{array}{l}\% \text { (relative } \\
\text { to colonies } \\
\text { screened) }\end{array}$ \\
\hline \multirow[t]{2}{*}{$\mathrm{RD} 672$} & $50 \mu \mathrm{g} / \mathrm{mL} \mathrm{NTG}^{2}$ & 10,600 & 19 & 0.179 \\
\hline & None $^{3}$ & 23,700 & 5 & 0.021 \\
\hline \multirow[t]{2}{*}{ RD674 } & $5 \mu \mathrm{g} / \mathrm{mL} \mathrm{NTG}^{2}$ & 12,000 & 11 & 0.092 \\
\hline & None & 54,900 & 14 & 0.026 \\
\hline \multirow[t]{2}{*}{ RD677 } & $5 \mu \mathrm{g} / \mathrm{mL} \mathrm{NTG}^{2}$ & 12,100 & 13 & 0.107 \\
\hline & None & 25,900 & 6 & 0.023 \\
\hline \multirow[t]{2}{*}{ RD678 } & $10 \mu \mathrm{g} / \mathrm{mL} \mathrm{NTG}^{2}$ & 5800 & 22 & 0.379 \\
\hline & None & 46,300 & 3 & 0.006 \\
\hline
\end{tabular}

${ }^{1}$ Mutants that do not hydrolyze urea.

${ }^{2}$ The concentration of NTG ( $N$-methyl- $N$ '-nitro- $N$-nitrosoguanidine) was adjusted to obtain $50 \%$ lethality.

${ }^{3}$ Spontaneous mutation.

treatment or by spontaneous mutation were unable to hydrolyze urea.

\section{Stability and Urease Activity of the Mutants}

Stability of the ur(-) mutants was studied by performing 20 successive transfers in M17 broth. Each subculture was inoculated at $2 \%$ and incubated for $24 \mathrm{~h}$ at $37^{\circ} \mathrm{C}$, which was equivalent to approximately 110 generations. Only 3 of the 93 ur(-) mutants were found to be unstable (presence of at least $1 \%$ of urea-hydrolyzing colonies after 20 transfers). One of these unstable mutants was a spontaneous mutant of strain RD672, and the 2 others resulted from mutagen treatment of strain RD678. Urease activity of strains RD672, RD674, RD677, and RD678 was 1.13, 2.45, 0.98, and $2.38 \mathrm{U} / \mathrm{mg}$ of protein, respectively, whereas no activity could be detected $(<0.02 \mathrm{U} / \mathrm{mg}$ protein) in any of the 90 stable mutants. Absence of urea hydrolysis by the mutants, thus, is the result of an absence of functional urease.

\section{Resistance of the Mutants to Bacteriophages}

Inhibition of starter cultures by bacteriophages poses a significant problem in industrial practice. The 4 parent strains and the 90 stable mutants were tested for sensitivity to 41 bacteriophages from the Rhodia food collection, as described in Materials and Methods. Streptococcus thermophilus RD672 was sensitive to none of the 41 bacteriophages. Sixteen of the 23 mutants selected from RD672 had the same property, whereas the others were sensitive to between 1 and 5 bacteriophages (data not shown). Streptococcus thermophilus RD674 was sensitive to one bacteriophage. The mutants selected from this strain had the same sensitivity profile, except one of them, which became resistant to all bacteriophages. 
Streptococcus thermophilus RD677 was sensitive to 12 bacteriophages. The ur(-) mutants selected from this strain were sensitive to between 11 and 20 bacteriophages. The parent strain RD678 was sensitive to 2 bacteriophages. Nineteen of the 23 stable mutants selected from RD678 had the same property; 3 of them were resistant to all bacteriophages, and one of them was sensitive to 3 bacteriophages. Thus, there were only small differences in bacteriophage sensitivity profile between the parent strains and the mutants. As there was no general trend, these differences were probably not the direct consequence of the loss of urea-hydrolyzing ability.

\section{Genetic Investigation of the Spontaneous Mutants}

It was surprising that, for the 4 parent strains, a high rate of spontaneous urease-deficient mutants were obtained. According to Neidhardt et al. (1990), spontaneous mutations are often deletions. The nucleotide sequence corresponding to the genes ureI, ureA, ureB, ureC, ureE, ure $F$, ure $G$, and ureD from $S$. thermophilus $\mathrm{RD} 678$ was determined after PCR amplification using oligonucleotides deduced from the $S$. salivarius urease operon sequence. The sequence (deposited in Genbank under the accession number AY374143) has a high homology with that of S. salivarius. Homology varied between $96 \%$ for peptide ureD to $100 \%$ for peptide ureG. Using the nucleotide sequence from $S$. thermophilus RD678, we chose 9 couples of oligonucleotides that cover the 8 ure genes (see Materials and Methods). Polymerase chain reaction amplifications using these oligonucleotides were performed on all 27 spontaneous urease-deficient mutants that were stable. Twenty-six of these mutants showed no difference in the size of the fragments generated by PCR amplification. However, strain RD678-7(0), a mutant selected from $S$. thermophilus RD678, had a higher size of DNA fragment with the couple of oligonucleotides ur37/ur39 (2.3 kb instead of $0.9 \mathrm{~kb})$. Sequencing of this fragment showed the presence of a 1416-bp insertion sequence element, named ISSth1. This sequence (deposited in Genbank under the accession number AY376237) contained an open reading frame corresponding to a peptide of 434 amino acids. The peptide showed significant homology (72\% identity) with a transposase present in the IS1167 insertion sequence element from $S$. pneumoniae (Tettelin et al., 2001). In mutant RD678-7(0), insertion of ISSth1 occurred within the intergenic region between $u r e C$ and $u r e D$. ISSth1 does not affect the ureC open reading frame. It is possible that it has a pleiotropic effect on the downstream genes (ureE, ureF, ure $G$, and $u r e D)$ and thus precludes production of an active urease.

\section{Acidifying Activity of the Mutants in Milk}

The 4 parent strains and the 90 stable ur(-) mutants were grown in reconstituted skim milk. Figure 1 shows

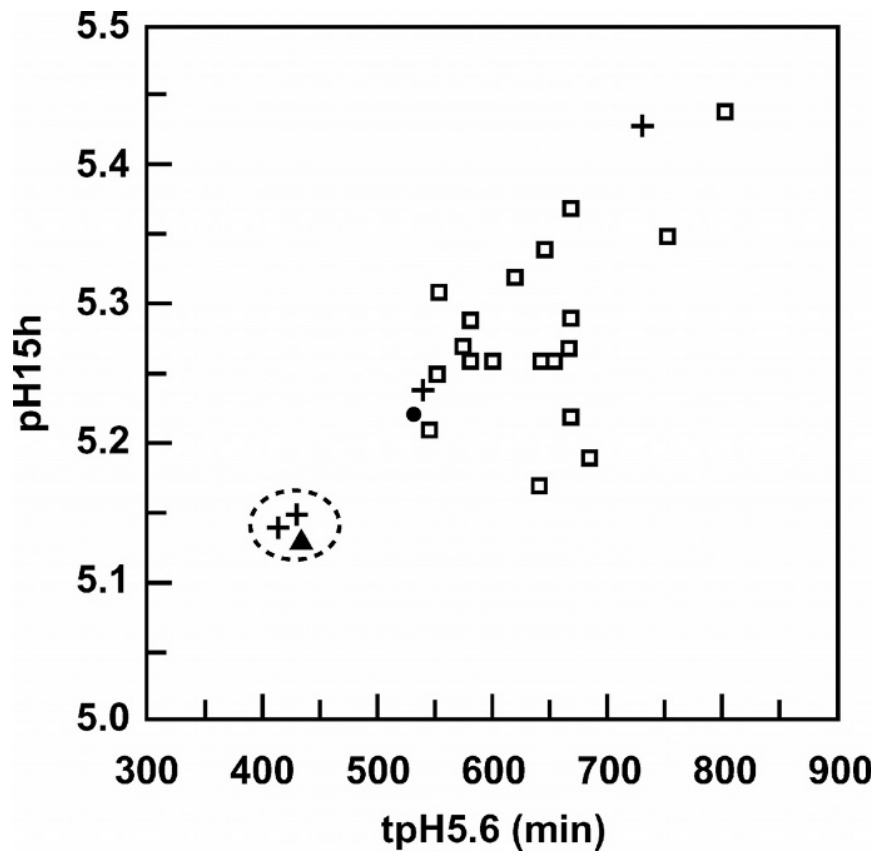

Figure 1. Acidifying activity of Streptococcus thermophilus RD672 and its $\operatorname{ur}(-)$ mutants (mutants that are unable to hydrolyze urea). Values of the $\mathrm{pH}$ after $15 \mathrm{~h}$ of growth (pH15h) vs. the time necessary to reach pH 5.6 (tpH5.6) in milk cultures of the parent strain ( ), of spontaneous mutants $(+)$, of mutants selected after mutagen treatment $(\square)$, and of the parent strain in the presence of flurofamide (A). Mutants whose tpH5.6 and $\mathrm{pH} 15 \mathrm{~h}$ values were not significantly different from the values of the parent strain in the presence of flurofamide are surrounded by a broken line.

the values of $\mathrm{pH} 15 \mathrm{~h}$ as a function of tpH5.6 in cultures of the parent strain RD672 and its mutants. Addition of the urease inhibitor flurofamide increased the acidifying activity of the parent strain. Indeed the tpH5.6 and $\mathrm{pH} 15 \mathrm{~h}$ values were significantly lower $(P<0.05)$ in the presence of this compound. Theoretically, the acidifying activity of the ur(-) mutants should be similar to that of the parent strain cultivated in the presence of flurofamide, except if the mutants contain detrimental nonspecific mutations. Only 2 of the 4 spontaneous mutants had tpH5.6 and pH15h values similar to those of the parent strain cultivated in the presence of flurofamide. The other spontaneous mutants were less acidifying (significantly higher values of tpH5.6 and pH15h). Furthermore, all of the mutants selected after NTG treatment were less acidifying than the parent strain cultivated in the presence of flurofamide (significantly higher values of tpH5.6 or of tpH5.6 and pH15h). Evolution of pH as a function of time during growth of strain RD672 in milk supplemented or not with flurofamide and of 2 spontaneous mutants is shown in Figure 2. One of these mutants, namely RD672-47(0), displayed the theoretical acidifying activity (i.e., the activity of the parent strain in 


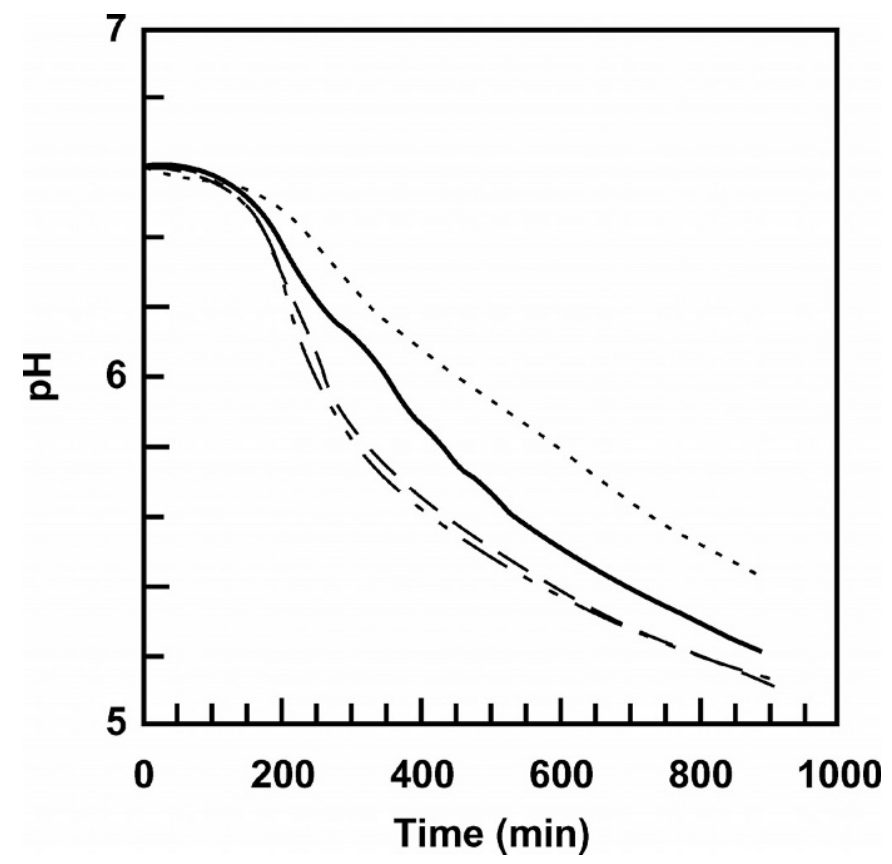

Figure 2. Evolution of $\mathrm{pH}$ during the growth of Streptococcus thermophilus RD672 in milk (- - , in milk supplemented with flurofamide (- - - ), and of the spontaneous ur(-) mutants RD672-47(0)

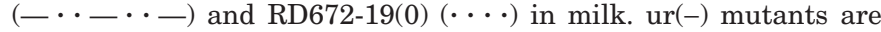
mutants that are unable to hydrolyze urea.

the presence of flurofamide), whereas the second mutant (RD672-19(0)) was much less acidifying.

Addition of flurofamide increased the acidifying activity of the parent strain RD674. Indeed, the tpH5.6 value was significantly lower $(P<0.05)$ in the presence of this compound (data not shown). The acidifying activity of 3 of the 14 spontaneous mutants and of 2 of the 11 mutants selected after NTG treatment was similar to that of the parent strain cultivated in the presence of flurofamide. All of the other mutants had a significantly higher pH15h value $(P<0.05)$.

As for RD674, flurofamide increased the acidifying activity of strain RD677 (decrease of tpH5.6) (data not shown). The acidifying activity of all 6 spontaneous mutants was similar to that of the parent strain cultivated in the presence of flurofamide (no significant difference in tpH5.6 and pH15h). However, similar behavior was observed with only 2 of the 13 mutants selected after NTG treatment.

Flurofamide increased the acidifying activity of strain RD678 (decrease of tpH5.6) (data not shown). The acidifying activity of all 3 spontaneous mutants was similar to that of the parent strain cultivated in the presence of flurofamide (no significant difference in tpH5.6 and $\mathrm{pH} 15 \mathrm{~h}$ ). However, similar behavior was observed with only 8 of the 20 mutants selected after NTG treatment.

\section{DISCUSSION}

Urea metabolism by $S$. thermophilus has a significant effect on the acidifying properties of this lactic acid bacterium (Pernoud et al., 2004). The objective of the present study was to select and to characterize $S$. thermophilus mutants that do not hydrolyze urea. Using an improved screening method on agar plates, ur(-) mutants could be selected from 4 different parent strains. All of these mutants lacked an active urease. Surprisingly, spontaneous ur(-) mutants appeared at an unusually high rate. Indeed, depending on the parent strain, between 0.006 and $0.026 \%$ of the colonies were unable to hydrolyze urea. In Lactobacillus delbrueckii ssp. bulgaricus, another thermophilic lactic acid bacterium, a high spontaneous mutation rate has been observed for the $\beta$-galactosidase (Mollet and Delley, 1990). This could be linked to the formation of spontaneous deletions within the $\beta$ galactosidase gene, the most frequent event being a 150bp deletion. No deletion could be detected in any of the 8 ure genes of the $S$. thermophilus spontaneous ur(-) mutants. However, presence of small deletions cannot be excluded, as electrophoresis of the DNA fragments that have been PCR-amplified does not make it possible to detect size changes smaller than approximately 50 bp. For mutant RD678-7(0), absence of urease activity was probably due to the presence of an insertion sequence element within the urease operon. However, this does not explain the high spontaneous mutation rate, as no such element could be detected in any other of the mutants. Thus, it is thus likely that in most ur(-) spontaneous mutants, absence of a functional urease is due to point mutations or to small insertions or deletions.

As most ur(-) mutants were stable for $>110$ generations, it is likely that the competitive growth advantage of $\operatorname{ur}(+)$ reverting mutants is only limited. Thus, utilization of ur(-) mutants in industrial processes would probably not be hampered by a lack of stability of the ur(-) phenotype. Furthermore, on average, these mutants were not more sensitive to bacteriophages than the parent strains.

Addition of the urease inhibitor flurofamide has no other effect on growth and acidifying activity of $S$. thermophilus than that resulting from inhibition of urease (Pernoud et al., 2004). Cultivation of parent strains in the presence of flurofamide is thus representative of cultures of ur(-) mutants that do not contain detrimental nonspecific mutations (i.e., other than those affecting urease activity). The proportion of ur(-) mutants displaying the theoretical acidifying activity was much higher in the case of spontaneous mutants than for mutants selected after NTG treatment. This result was expected, as mutagen treatments often induce multiple mutations in the cells. For 2 of the parent strains investi- 
gated in the present study, all spontaneous ur(-) mutants displayed the theoretical acidifying activity. Thus, we recommend that ur(-) mutants intended to be used in dairy processes should preferably be selected by spontaneous mutation.

It is expected that replacement of $S$. thermophilus strains by their ur(-) spontaneous mutants in cheesemaking processes would have several advantages. First, in some strains, for example RD678 (Pernoud et al., 2004), urea metabolism is responsible for a temporary increase of $\mathrm{pH}$ that considerably delays acidification (depending on culture conditions). Thus, suppression of urea consumption would increase the acidifying activity of these strains. Second, when $S$. thermophilus strains are present, variations of urea concentration in milk affect the $\mathrm{pH}$ evolution kinetics, which may have negative consequences on the quality of cheeses (Martin et al., 1997). This problem would be suppressed by using ur(-) mutants. Finally, ammonia production by $S$. thermophilus increases the ammonia content of cheese whey, which results in a lower commercial value of this byproduct. This problem could be alleviated by using ur(-) mutants.

\section{CONCLUSIONS}

The present study shows that urease-deficient mutants of $S$. thermophilus can be easily selected by spontaneous mutation. Most of these mutants are stable, and absence of detrimental nonspecific mutations (i.e., other than those concerning urease activity) can be checked by comparing the properties of the mutants to those of the parent strain cultivated in the presence of flurofamide. Utilization of these urease-deficient mutants in cheesemaking processes may have several advantages.

\section{ACKNOWLEDGMENTS}

We thank Annie Mornet, Loïc Pellerin, Isabelle Chavichvily, and Jérôme Delettre for helpful discussion and technical assistance. We are also grateful to Christine Young for critically reading the manuscript.

\section{REFERENCES}

Bradford, M. M. 1976. A rapid and sensitive method for the quantitation of microgram quantities of protein utilizing the principle of protein-dye binding. Anal. Biochem. 72:248-254.
Chen, Y. Y., and R. A. Burne. 1995. Molecular analysis of the urease of Streptococcus salivarius strain 57.1. Dev. Biol. Stand. 85:387-392.

Chen, Y. Y., K. A. Clancy, and R. A. Burne. 1996. Streptococcus salivarius urease: Genetic and biochemical characterization and expression in a dental plaque streptococcus. Infect. Immunol. 64:585-592.

Chen, Y. Y. M., H. Thomas, and R. A. Burne. 1998. Streptococcus salivarius urease expression: Involvement of the phosphoenolpyruvate:sugar phosphotransferase system. FEMS Microbiol. Lett. 165:117-122.

Corrieu, G., H. E. Spinnler, D. Picque, and Y. Jomier, inventors. 1988. Automated system to follow up and control the acidification activity of lactic acid starters. Fr. Pat. Appl. FR2629612.

Devereux, J., P. Haeberli, and O. Smithies. 1984. A comprehensive set of sequence analysis programs for the VAX. Nucleic Acids Res. 12:387-395.

Farrow, J. A., and M. D. Collins. 1984. DNA base composition, DNADNA homology and long-chain fatty acid studies on Streptococcus thermophilus and Streptococcus salivarius. J. Gen. Microbiol. 130:357-362.

Juillard, V., M. J. Desmazeaud, and H. E. Spinnler. 1988. Mise en évidence d'une activité uréasique chez Streptococcus thermophilus. Can. J. Microbiol. 34:818-822.

Latrille, E., D. Picque, B. Perret, and G. Corrieu. 1992. Characterizing acidification kinetics by measuring $\mathrm{pH}$ and electrical conductivity in batch thermophilic lactic fermentations. J. Ferment. Bioeng. 74:32-38.

Martin, B., J. B. Coulon, J. F. Chamba, and C. Bugaud. 1997. Effect of milk urea content on characteristics of matured Reblochon cheeses. Lait 77:505-514.

Mollet, B., and M. Delley. 1990. Spontaneous deletion formation within the $\beta$-galactosidase gene of Lactobacillus bulgaricus. J. Bacteriol. 172:5670-5676.

Neidhardt, F. C., J. L. Ingraham, and M. Schaechter. 1990. Physiology of the Bacterial Cell. A Molecular Approach. Sinauer Associates, Inc., Sunderland.

Pernoud, S., C. Fremaux, A. Sepulchre, G. Corrieu, and C. Monnet. 2004. Effect of the metabolism of urea on the acidifying activity of Streptococcus thermophilus. J. Dairy Sci. 87:550-555.

Pospiesh, A., and B. Neumann. 1995. A versatile quick-prep of genomic DNA from gram-positive bacteria. Trends Genet. 11:217-218.

Spinnler, H. E., and G. Corrieu. 1989. Automatic method to quantify starter activity based on $\mathrm{pH}$ measurement. J. Dairy Res. 56:755-764.

Terzaghi, B. E., and W. E. Sandine. 1975. Improved medium for lactic streptococci and their bacteriophages. Appl. Microbiol. 29:807-813.

Tettelin, H., K. E. Nelson, I. T. Paulsen, J. A. Eisen, T. D. Read, S. Peterson, J. Heidelberg, R. T. DeBoy, D. H. Haft, R. J. Dodson, A. S. Durkin, M. Gwinn, J. F. Kolonay, W. C. Nelson, J. D. Peterson, L. A. Umayam, O. White, S. L. Salzberg, M. R. Lewis, D. Radune, E. Holtzapple, H. Khouri, A. M. Wolf, T. R. Utterback, C. L. Hansen, L. A. McDonald, T. V. Feldblyum, S. Angiuoli, T. Dickinson, E. K. Hickey, I. E. Holt, B. J. Loftus, F. Yang, H. O. Smith, J. C. Venter, B. A. Dougherty, D. A. Morrison, S. K. Hollingshead, and C. M. Fraser. 2001. Complete genome sequence of a virulent isolate of Streptococcus pneumoniae. Science 293:498-506.

Tinson, W., M. C. Broome, A. J. Hillier, and G. R. Jago. 1982a. Metabolism of Streptococcus thermophilus. 2. Production of $\mathrm{CO}_{2}$ and $\mathrm{NH}_{3}$ from urea. Aust. J. Dairy Technol. 37:14-16.

Tinson, W., M. F. Ratcliff, A. J. Hillier, and G. R. Jago. 1982b. Metabolism of Streptococcus thermophilus. 3. Influence on the level of bacterial metabolites in cheddar cheese. Aust. J. Dairy Technol. 37:17-21. 